\title{
У Täydentävien ja vaihtoehtoisten (CAM) hoitojen käyttö Suomessa
}

Tarkastelemme tässä artikkelissa täydentävien ja vaihtoehtoisten hoitojen käyttöä Suomessa vuosina 2008 ja 2018. Täydentävillä ja vaihtoehtoisilla hoidoilla tarkoitetaan monimuotoista joukkoa erilaisia hoitomuotoja, joita ei tietyssä historiallisessa ja yhteiskunnallisessa tilanteessa pidetä valtavirtalääkinnän osana eikä niitä ole integroitu terveydenhoitojärjestelmään. CAMhoitojen käyttö virallisesti hyväksyttyjen hoitomenetelmien sijasta tai ohella on merkittävä, mutta maassamme vähän tutkittu ilmiö. Tutkimuksen tarkoituksena on selvittää, miten paljon suomalaiset käyttävät CAM-hoitoja ja millaisia muutoksia käytössä on tapahtunut vuodesta 2008 vuoteen 2018. Tarkastelimme, millaisia hoitoja suomalaiset käyttävät sekä sitä, kokivatko käyttäjät saaneensa hoidosta apua. Tutkimme myös, millaisia mielikuvia suomalaisilla oli eri hoitomuotojen mahdollisuuksista parantaa jokin sairaus. Tutkimusaineistona käytimme Taloustutkimuksen keräämiä kyselyitä, joita analysoimme Khiin neliön testillä, eksploratiivisella pääkomponenttianalyysillä ja lineaarisella regressioanalyysillä.

Tulostemme mukaan CAM-hoitojen käyttö oli vähentynyt viimeisen kymmenen vuoden tarkastelujaksolla. Käytetyimmät hoitomuodot olivat suun kautta otettavat tuotteet (luontaistuotteet, ravintolisät ja rohdosvalmisteet). Muita yleisesti käytettyjä hoitomuotoja olivat rukous, akupunktio ja kiropraktiikka. Vaikka yleinen usko hoitojen parantavuuteen oli laskenut, niin hoitoja käyttäneet kokivat edelleen saaneensa hoidoista apua. Terapioita, joihin sisältyy asiantuntijan hoidettavana oleminen, käyttivät eniten naiset ja vanhemmat ikäluokat. CAM-hoitojen ja valtavirtalä̈etieteen käyttö eivät olleet tilastollisesti merkitsevästi yhteydessä toisiinsa eli CAM-hoidot eivät vähentäneet valtavirtalääketieteen käyttöä. Vastaajat hakivat apua laajasti eri hoitomuodoista.

ASIASANAT: täydentävät ja vaihtoehtoiset hoidot, CAM, CAM-hoitojen käyttö, uskomuslääkintä, Suomi

PIA VUOLANTO, LAURA KEMPPAINEN, TEEMU KEMPPAINEN, JOHANNA NURMI

\section{YDINASIAT}

- Suomalaisten täydentävien ja vaihtoehtoisten (CAM) hoitojen käytöstä tiedetään vähän

- CAM-hoitojen käyttö oli vähentynyt kymmenen vuoden aikana

- Käytetyimmät hoitomuodot olivat suun kautta otettavat tuotteet (luontaistuotteet, ravintolisät ja rohdosvalmisteet) ja muita yleisesti käytettyjä hoitomuotoja olivat rukous, akupunktio ja kiropraktiikka
- Kyselyitä on kehitettävä, että CAM-hoitojen käytöstä saadaan tietoa hoitojen sääntelyä ja väestön terveydenhoitokeinojen seurantaa varten 


\section{JOHDANTO}

\section{MITÄ OVAT CAM-HOIDOT?}

Tarkastelemme tässä artikkelissa täydentävien ja vaihtoehtoisten hoitojen käyttöä Suomessa vuosina 2008 ja 2018. Täydentävillä ja vaihtoehtoisilla hoidoilla tarkoitamme monimuotoista joukkoa erilaisia terveyden hoitamisen tapoja. Suomessa vuonna 2009 tehty selvitys vaihtoehtohoidoista listasi Suomessa yleisesti käytössä oleviin terapiamuotoihin antroposofisen lääketieteen, aromaterapian, fytoterapian, homeopatian, kajavaterapian, perinteisen suomalaisen jäsenkorjauksen, perinteisen kiinalaisen lääketieteen ja vyöhyketerapian, mutta samalla selvityksessä arveltiin, että erilaisia hoitomuotoja saattaa olla maassamme jopa 100-200 (1). Sen sijaan, että listattaisiin kaikki hoitomuodot, on tutkimuksissa pyritty luokittelemaan niitä (2-4). Yhdysvaltalaisessa selvityksessä vuodelta 2005 (5) hoitomuotoja luokiteltiin niiden oletetun vaikutuksen mukaan seuraavasti:

- Energiahoidot (kuten qi gong, reiki, terapeuttinen kosketus), joissa vaikutetaan kehoon energiakentillä,

- Manipulatiivisethoidot (kiropraktiikka,hierontahoidot), jotka perustuvat kehon liikutteluun,

- Kehomielihoidot (hypnoosi, meditaatio, rentoutushoidot), joilla vaikutetaan kehoon mielen avulla,

- Luontaistuotteet (yrttivalmisteet, vitamiinit, ruokavaliohoidot), joissa hyödynnetään kasvien lääkinnällisiä vaikutuksia tai erilaisia ruokavalio- ja paastohoitoja,

- Terveydenhoitojärjestelmät (kiinalainen lääkintä, auyrvedinen lääkintä, antroposofinen lääkintä, homeopatia), jotka muodostavat kokonaisia lääketieteestä selkeästi erottuvia terveydenhoidon kokonaisuuksia.

Yksi tätä laajempi täydentävien ja vaihtoehtoisten hoitojen luokitustapa on Yhdysvaltain kansallisen lääketieteen kirjaston luokitusjärjestelmässä (Medical Subject Headings, MeSH; 6), jossa hakutermi 'complementary therapies' sisältää laajan kirjon hoitoja (7). Hakutermi kuvaa, mitä hoitoja kansainvälisessä lääketieteen sanastossa sisällytetään näihin hoitoihin.

Suomessa julkisessa keskustelussa täydentävistä ja vaihtoehtoisista hoitomuodoista käyte- tään esimerkiksi termejä uskomuslääkintä, huuhaa, puoskarointi, täydentävä hoito, vaihtoehtoinen hoito, yhdistävä tai integroiva hoito, luontaishoito, CAM-hoito, perinnehoito tai perinteinen hoito ja lääketieteen ulkopuolinen hoito $(8,9)$. Termeillä pyritään ottamaan kantaa keskusteluissa, joissa kiistellään hoitojen käyttökelpoisuudesta terveyden hoitokeinoina (10). Osa termeistä on latautuneita ja niillä ilmaistaan omaa kantaa kiistoissa. Esimerkiksi termillä uskomuslääkintä liitetään eri terapiamuodot ihmeisiin ja yliluonnollisiin voimiin ja luodaan vastakkainasettelua potilaiden ja lääkäreiden välillä $(11,12)$. Artikkelimme tarkoituksena ei ole ottaa kantaa kiistoihin, joten olemme pyrkineet löytämään mahdollisimman neutraalin termin, jolla kuvata täydentäviä ja vaihtoehtoisia hoitoja. Kansainvälisessä tutkimuskirjallisuudessa näistä hoitomuodoista käytetään yleisimmin käsitettä täydentävä ja vaihtoehtoinen lääkintä (CAM= complementary and alternative medicine) tai täydentävät ja vaihtoehtoiset hoidot $(2,3)$. Käytämme jatkossa artikkelissa CAM-lyhennettä, vaikka sekään ei ole aivan puolueeton termi $(10,13)$.

Suhtautuminen CAM-hoitoihin vaihtelee kulttuurista ja hoitomuodosta toiseen sekä väestössä että terveydenhuollon ammattilaisten keskuudessa (10,14-15). CAM-hoidoiksi luokitelluista hoitomuodoista esimerkiksi akupunktio, osteopatia ja naprapatia ovat Suomessa Valviran nimekesuojattuja ammattinimikkeitä (16). Joidenkin hoitojen tehokkuudesta on tehty lääketieteen piirissä tutkimuksia, joista osa kliinisiä kokeita (17). Tutkimuksia tehtiin etenkin kehomielihoidoista, taideterapioista (MeSH-luokituksessa 'sensory art therapies'), akupunktuurista, fytoterapiasta ja manipulatiivisista hoidoista (17). Joitakin CAM-hoitoja voidaankin pitää näyttöön perustuvina (18-19). Usein rajanveto CAM-hoitojen ja muun lääkinnän välillä on kuitenkin etenkin maallikolle vaikeaa ja tutkimustiedon vähäisyyden vuoksi jako tehottomiin ja haitallisiin hoitoihin on haastavaa myös terveydenhuollon ammattilaisille.

\section{CAM-KÄYTTÖTUTKIMUKSEN HAASTEET}

Vakiintumattomat CAM-hoitojen määritelmät vaikeuttavat vertailututkimuksia (20). Joissakin tutkimuksissa CAM-hoidoksi on määritelty esim. kasvis- ja vegaaniruokavalio sekä hieronta, mutta toisaalta lisäravinteiksi ei ole laskettu vitamiini- 
ja hivenainevalmisteita. Sellaisetkin kokonaisuudet kuin perusvitamiinit, liikunta ja ruokavalio lasketaan joissakin luokituksissa ja monissa tutkimuksissa CAM-hoidoiksi. Se lisännee käyttöastetta huomattavasti verrattuna siihen, jos niitä (ja esim. klassista hierontaa) ei laskettaisi mukaan. Vitamiinien määrittely joissakin tutkimuksissa CAM-hoidoiksi on esimerkkinä CAM-hoitojen ja virallisten hoitojen liukuvasta rajasta (14). Joskus kysyttyjä hoitoja muutetaan vastaamaan muutoksia, jotka aiheutuvat joidenkin CAM-hoitojen muututtua harvinaisemmiksi tai toisten vastaavasti suositummiksi. Esimerkiksi sinänsä vertailukelpoiseen yhdysvaltalaistutkimukseen kysyttyihin hoitomuotoihin oli vuonna 2017 lisätty naturopatia, homeopatia, parantajalla käynti, eri rentoutumistekniikat, eri meditaatiotekniikat sekä jooga (21).

Tutkimuksissa käytetyt erilaiset tavat luokitella CAM-hoitoja hankaloittavat niin käytön ajallisen muutoksen seurantaa kuin maiden välistä vertailua. Hoitoja on jaoteltu esimerkiksi perinnelääkintään, manuaalisiin terapioihin, kehomieli-terapioihin, luonnonlääkintään ja muihin lääkintäjärjestelmiin (2). Monissa viimeaikaisissa CAM-hoitojen käyttöä tarkastelevissa tutkimuksissa luokitellaan hoitoja perustuen esimerkiksi amerikkalaisen National Center for Complementary and Integrative Health, NCCIH (aiemmin National Center for Complementary and Alternative Medicine, NCCAM) keskuksen jaotteluun, joka luokittelee CAM-hoidot kolmeen eri kategoriaan: 1) ulkoisesti ja sisäisesti käytettävät valmisteet (esim. yrtit, vitamiinit ja lisäravinteet), 2) keho-mielihoidot (esim. akupunktio, osteopatia, jooga, meditaatio) ja 3) kokonaiset hoitojärjestelmät (esim. kansanparannus, homeopatia, kiinalainen lääketiede) (3). Tätä edeltäneessä luokituksessa, jonka esitimme artikkelin alussa, jaoteltiin erikseen myös 4) manipulatiiviset hoidot sekä 5) energiahoidot (22). Itse olemme aiemmin käyttäneet tähän perustuvaa luokittelua eurooppalaisessa vertailututkimuksessa, jossa hoidot kategorisoitiin aasialaiseen perinnelääkintään, vaihtoehtoiseen lääkintään, manuaalisiin terapioihin ja keho-mieli -terapioihin (4).

Eri tutkimusten vertailua hankaloittaa myös se, että kyselyissä CAM-hoidot saatetaan esittää vastaajille listaten lukuisia yksittäisiä hoitomuotoja tai useita hoitomuotoja yhdistäviä kategorioita, tai hoitojen käytöstä saatetaan kysyä avoimilla kysymyksillä. Eri kysymystapojen on katsottu vaikuttavan käytön raportoimiseen esimerkiksi siten, että yksittäisten hoitojen listaaminen lisäisi käytön raportointia, kun taas avoimet kysymykset vähentäisivät sitä, koska vastaaja ei välttämättä muista käyttäneensä CAM-hoitoa tai ei ajattele käyttämänsä hoidon lukeutuvan CAM-hoitoihin (20). Myös kyselyissä käytetty ajallinen ulottuvuus vaikuttaa käytön raportointiin. Käytön tutkimusta onkin pyritty standardoimaan, jotta voitaisiin kerätä kansainvälisesti vertailukelpoista aineistoa $(20,23,24)$.

\section{CAM-HOITOJEN KÄYTÖN TUTKIMUS}

CAM-hoitojen käyttöä tutkitaan terveyssosiologian alalla $(10,25)$. Tieto hoitojen käytöstä on tärkeää ilmiön laajuuden ja Suomen terveydenhoitokeinojen monimuotoisuuden ymmärtämiseksi (12). Tällainen tieto voi olla tarpeen pohdittaessa CAM-hoitojen sääntelyä (1). Hoitojen käytön laajuuden ymmärtäminen on merkittävää myös terveydenhuollon ammattilaisille, kun he pohtivat, miten toimia CAM-hoitoja käyttävien kanssa terveydenhuollon kohtaamisissa (esim. 26) ja terveysalan koulutusorganisaatioille, kun ne määrittävät terveydenhuollon ammattilaisten CAM-hoitoja koskevia koulutustarpeita (1). On myös tärkeää tuntea Suomen sisäisiä alueellisia eroja CAM-hoitojen käytössä, jotta ihmisten terveyskäyttäytymistä voidaan ennakoida ja ymmärtää.

CAM-hoitojen käyttö vakiintuneiden hoitojen sijasta tai ohella on merkittävä, mutta maassamme vähän tutkittu ilmiö (14). CAM-hoitojen käytön yleisyyttä alettiin Suomessa tutkia 1970-luvun lopulla (14). Vuosina 1982 ja 1992 käytön yleisyyttä selvitettiin kyselyillä. Vuoden 1982 kyselyyn vastanneista yrttihoitoja oli käyttänyt $17 \%$ vastaajista, hierontaa $11 \%$, jäsenkorjausta $4 \%$, rentoutushoitoja $5 \%$, akupunktiota $2 \%$ ja kuppausta $0,5 \%$ ja muuta kansanparannusta 1\% (27). Vuoden 1992 tutkimuksessa 37\% vastaajista oli käyttänyt luontaistuotteita tai luonnonlääkkeitä viimeisen puolen vuoden aikana. Naiset käyttivät CAM-hoitoja jonkin verran enemmän kuin miehet. Yleisimmin oli käyty kiropraktikoiden, naprapaattien ja vyöhyketerapeuttien vastaanotoilla. (28)

Kansainväliset vertailututkimukset, vaikka niissä kysytyt hoitomuodot vaihtelevat, tuovat valaistusta CAM-hoitojen käytön nykytilantee- 
seen Suomessa. Vuonna 2014 tehdyssä eurooppalaisessa vertailututkimuksessa (European Social Survey -aineistolla) suomalaisten CAM-hoitojen käyttö nousi verrattain korkeaksi (35.3\%) kysyttäessä, oliko henkilö käyttänyt vähintään yhtä terapiamuotoa viimeisen 12 kuukauden aikana (4). Kaikkiaan 21 eurooppalaisen maan vertailussa eri maista vain Saksassa, Itävallassa ja Sveitsissä käyttö oli Suomea korkeammalla tasolla (4). Muissa pohjoismaissa tilanne oli samankaltainen kuin Suomessa: käyttöaste vaihteli Norjan 29 prosentista Tanskan 32 prosenttiin (4). Toisessa CAM-hoitopalvelujen kansainvälisessä vertailussa suomalaisten hoitopalvelujen käyttö puolestaan vaikuttaa maltilliselta; 2011-2013 kerätyn kyselyaineiston perusteella $15,7 \%$ suomalaisista oli käyttänyt viimeisen 12 kuukauden aikana perinne- tai vaihtoehtohoidon palveluntarjoajien antamia hoitoja, kun 32 maan vertailussa keskimääräinen käyttöaste oli 26,4\% (29).

Olisi tärkeää selvittää CAM-hoitojen käytössä tapahtuneita ajallisia muutoksia, mutta väestötason pitkän aikavälin seurantatutkimukset ovat harvinaisia (30). Jo varhaisissa suomalaisissa vuosien 1982 ja 1992 tutkimuksissa pyrittiin tekemään vertailua ja havaittiin kansanlääkinnän ja luontaislääkkeiden käytön lisääntyneen hieman kyseisenä aikana (31). Kanadalaisessa tutkimuksessa hyödynnettiin väestötason terveyskyselyä, joka mahdollisti 16 vuoden seurantatutkimuksen. Siinä todettiin CAM-hoitojen käytön lisääntyneen 5\% yli kymmeneen prosenttiin vuosien 1994-1995 ja 2010-2011 välillä (32). Yhdysvalloissa toteutetussa väestötason terveyskyselyssä aikuisväestön CAM-hoitojen yleisen käytön puolestaan todettiin pysyneen melko vakaana vuosina 2002-2012 (käyttöasteet 2002 32,3\%; 2007 35,5\%; 2012 33,2\%). Lisäravinteet (joiksi ei luettu vitamiineja ja hivenaineita) olivat Yhdysvalloissa suosituin CAM-hoidon muoto koko tarkasteluajanjaksolla, ja eniten kasvua oli tapahtunut joogan, tai chin ja qi gongin harjoittamisessa. (21) Vuoden 2017 terveyskysely osoitti joogan ja meditaation harjoittamisen edelleen lisääntyneen Yhdysvalloissa, ja lisäksi kiropraktiikan käyttö oli lisääntynyt vuodesta 2012 (33). Tsekkitutkimuksessa aikaväli oli kanadalaista ja amerikkalaista tutkimusta huomattavasti lyhyempi, eikä siinä ollut käytettävissä laajaa väestön terveystutkimusta, mutta siinäkin CAM-hoitojen käytön todettiin lisääntyneen vuodesta 2011 vuoteen 2014 (34).

\section{TUTKIMUKSEN TARKOITUS JA TUTKIMUSKYSYMYKSET}

Tutkimme CAM-hoitojen käyttöä kahtena ajankohtana, vuosina 2008 ja 2018. Käsittelemme sekä hoitojen käyttöä, uskoa hoitojen parantavuuteen että kokemuksia hoidoista saadusta avusta. Tuoreemman, vuoden 2018 aineiston avulla tarkastelemme myös, millaisia hoitomuotoja suomalaisessa väestössä käytetään tyypillisesti toistensa kanssa. Tutkimuksen tarkoituksena on selvittää, miten paljon suomalaiset käyttävät CAM-hoitoja ja millaisia muutoksia käytössä on tapahtunut vuodesta 2008 vuoteen 2018. Tarkastelemme, millaisia hoitoja suomalaiset käyttävät sekä sitä, kokevatko käyttäjät saaneensa hoidosta apua. Tutkimme myös, millaisia mielikuvia suomalaisilla on eri hoitomuotojen mahdollisuuksista parantaa jokin sairaus. Tutkimuskysymykset ovat:

1. Kuinka yleistä erilaisten hoitojen käyttö on ollut Suomessa vuosina 2008 ja 2018?

2. Onko käyttöaste muuttunut 2008-2018?

3. Onko usko hoitojen parantavuuteen, tai kokemus avun saamisesta muuttunut seuranta-aikana 2008-2018?

Vuoden 2018 osalta tutkimme lisäksi:

4. Mitkä sosiodemografiset tekijät liittyvät erilaisten CAM-hoitojen käyttöön?

5. Miten usko hoitojen parantavuudesta liittyy käyttöön?

6. Mitä yhteyksiä erilaisten CAM-hoitojen käytön välillä on?

\section{TUTKIMUKSEN AINEISTO JA MENETELMÄT}

Tutkimuksemme perustuu Taloustutkimuksen keräämiin kyselyaineistoihin vuosilta 2008 ja 2018. Aineistot kerättiin osana Taloustutkimuksen Omnibus-kyselyä, joka pohjautuu kiintiöpoiminnalla valittujen, 15-79-vuotiaiden Suomessa asuvien (Ahvenanmaa pois lukien) kasvokkaiseen haastatteluun. Valtaosa aineistosta on kerätty lähtöosoitemenetelmällä, jossa tietokoneella arvottu lähtöosoite on kiintiöity suuralueen ja kuntatyypin mukaan ja vastaajat on kiintiöity iän ja sukupuolen perusteella. Lisäksi haastatteluja kerättiin hallihaastatteluina Helsingissä, Tampereella ja Turussa, jolloin ohikulkevia henkilöitä pyydettiin osallistumaan käyttäen asuinalueen, iän ja sukupuolen mukaista kiintiöintiä. Lopuksi aineisto painotettiin jälkiosituksella vastaamaan perusjoukkoa käyttäen tarkempaa painotuskehikkoa, jossa on muun muassa enemmän ikäluokkia ja lisäksi talouden koko. Sama tiedonkeruuprotokolla oli käytössä kumpanakin tutkimusvuonna. (35). 
Taulukko 1. Vuosivertailu 2008-2018.

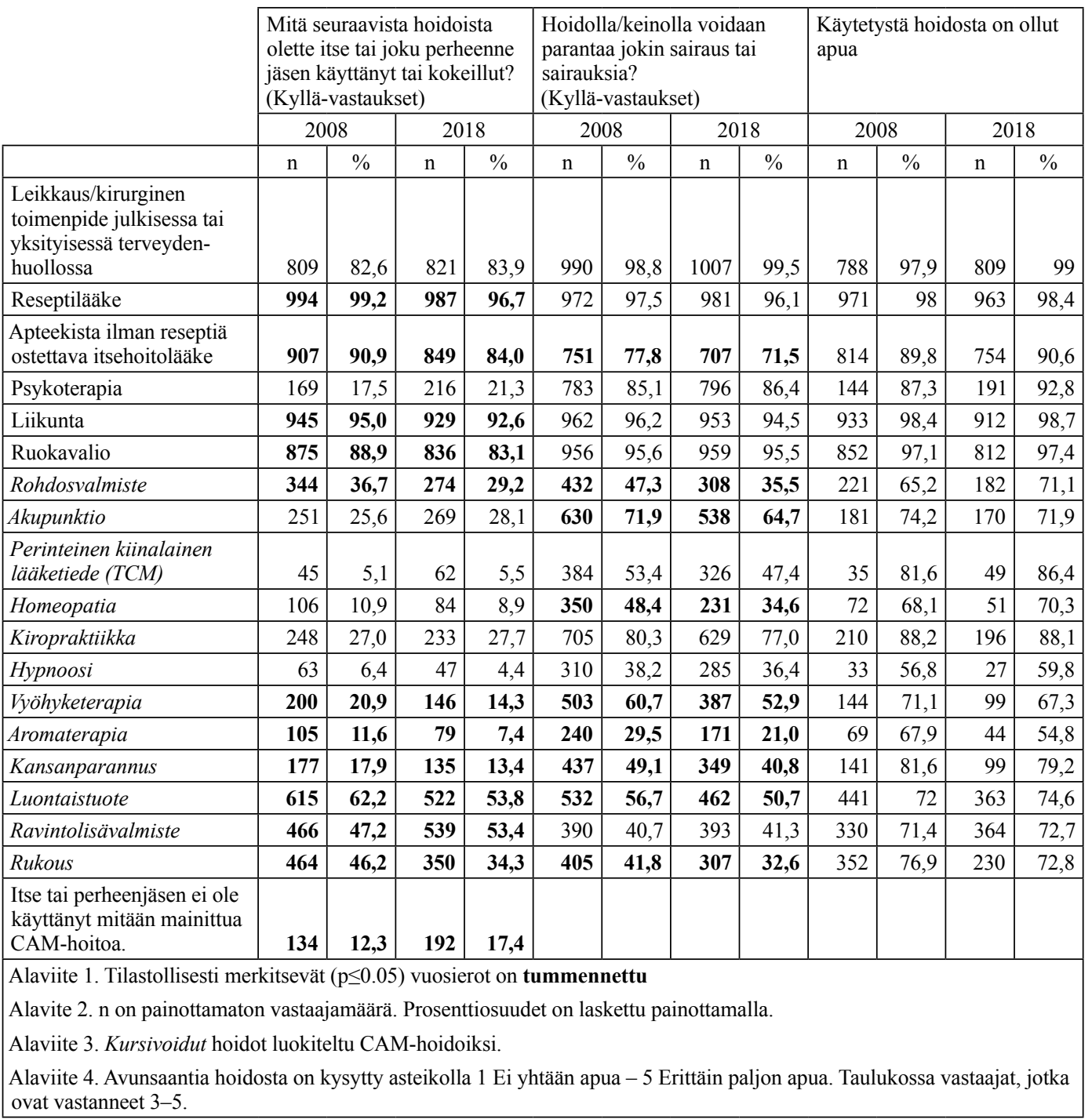

\section{MUUTTUJAT}

Vuosien 2008 ja 2018 vertailussa mukaan otettiin kysymykset "Ovatko seuraavat hoidot/keinot mielestänne sellaisia, joilla voidaan parantaa jokin sairaus tai sairauksia?” (Kyllä/Ei) "Entä mitä seuraavista hoidoista olette itse tai joku perheenne jäsen käyttänyt tai kokeillut?” (Kyllä/Ei) sekä "Miten paljon hoidoista, joita Te itse tai joku muu perheessänne on käyttänyt, on ollut apua?" (1 Ei lainkaan apua - 5 Erittäin paljon apua). Vastaajille annettiin lista 18 erilaisesta hoidosta, joihin kysymykset kohdistettiin. Määrittelimme näistä CAM-hoidoiksi luontaistuotteet, ravintolisävalmisteet, rohdosvalmisteet, kiropraktiikan, aku- punktion, vyöhyketerapian, kansanparannuksen, aromaterapian, homeopatian, hypnoosin, rukouksen, sekä perinteisen kiinalaisen lääketieteen, joita ei ole tarjolla julkisen terveydenhuollon piirissä. Lisäksi kysymykset kysyttiin koskien leikkausta tai kirurgista toimenpidettä, reseptilääkettä, apteekista ostettavaa itsehoitolääkettä, psykoterapiaa, liikuntaa ja ruokavaliota, joita käsittelemme muina kuin CAM-hoitoina. (Ks. taulukko 1). Luokittelimme CAM-hoidoiksi myös Valviran nimikesuojaamien ammattilaisten tarjoamista hoidoista kiropraktiikan ja akupunktion, koska ne kuuluvat kansainvälisissä luokituksissa CAMhoitoihin $(3,5,6)$. 
Taulukko 2. Muuttujakuvaukset (vuosi 2018; n=1020).

\begin{tabular}{|c|c|c|c|c|c|}
\hline & & $\mathrm{n}$ & $\begin{array}{c}\text { Keskiarvo } \\
\text { (keskihajonta) }\end{array}$ & Min & Max \\
\hline \multirow[t]{4}{*}{ Tulot } & Alle 20000 & 266 & & & \\
\hline & $20-40000$ & 253 & & & \\
\hline & $40-60000$ & 148 & & & \\
\hline & yli 60000 & 183 & & & \\
\hline \multirow[t]{3}{*}{ Koulutus } & Peruskoulu & 188 & & & \\
\hline & Toinen aste & 417 & & & \\
\hline & Korkeakoulu & 410 & & & \\
\hline Ikä & & 1020 & $46.8(18.9)$ & 15 & 79 \\
\hline \multirow[t]{2}{*}{ Sukupuoli } & Nainen & 555 & & & \\
\hline & Mies & 465 & & & \\
\hline \multirow[t]{4}{*}{ Päätoimi } & Työssä & 489 & & & \\
\hline & Työtön & 65 & & & \\
\hline & Opiskelija & 148 & & & \\
\hline & eläkeläinen & 318 & & & \\
\hline \multirow[t]{5}{*}{ Asuinpaikan koko } & Yli 100000 & 423 & & & \\
\hline & $50-100000$ & 144 & & & \\
\hline & $30-50000$ & 99 & & & \\
\hline & $10-30000$ & 247 & & & \\
\hline & alle 10000 & 107 & & & \\
\hline \multirow[t]{2}{*}{ CAM-usko } & CAM voi parantaa - summamuuttuja & 459 & $4.66(3.65)$ & 0 & 12 \\
\hline & $\begin{array}{l}\text { Vahva usko parantavuuteen } \\
\text { (ylin kvintiili) }\end{array}$ & 103 & & & \\
\hline \multirow{5}{*}{$\begin{array}{l}\text { Summamuuttujat } \\
\text { komponenteista }\end{array}$} & Terapia & 977 & $0.98(1.41)$ & 0 & 7 \\
\hline & Itsehoito & 974 & $2.14(1.32)$ & 0 & 4 \\
\hline & Elintavat & 1015 & $1.74(0.56)$ & 0 & 2 \\
\hline & Valtavirta & 1013 & $2.62(0.63)$ & 0 & 3 \\
\hline & Psykoterapia \& hypnoosi & 995 & $0.26(0.50)$ & 0 & 2 \\
\hline
\end{tabular}

Tutkiessamme uskoa CAM-hoitojen parantavuuteen muodostimme summamuuttujan kysymyksestä "Ovatko seuraavat hoidot/keinot mielestänne sellaisia, joilla voidaan parantaa jokin sairaus tai sairauksia?” (Kyllä/Ei) valitsemalla siihen CAM-hoitoja kuvaavat osiot. Tästä summamuuttujasta poimittiin voimakkaimmin näiden hoitojen tehoon uskovien kärki (20\%).

CAM-hoitojen käyttöasteen laskimme summamuuttujana CAM-hoidoista. Sosioekonomisista taustamuuttujista analyyseissa mukana ovat sukupuoli, ikä, koulutus, tulot, työllisyys sekä asuinalueen koko (ks. taulukko 2).

\section{MENETELMÄT}

Estimoimme CAM-hoitojen käyttöasteen ja 95\%:n luottamusvälit. Tutkimme erilaisten CAMhoitojen käytön ja parantavuususkon muutoksia Khiin neliö -testillä. Vuoden 2018 aineistolla tutkimme myös hoitomuotojen yhteisvaihtelua, jota analysoitiin ja tiivistettiin eksploratiivisella pääkomponenttianalyysilla (Varimax-rotaatio). Käyttäen tilastollisia kriteerejä ja sisällöllistä harkintaa päädyimme 5 komponentin ratkaisuun (ks. taulukko 3) ja tämän analyysin tulosten perusteella muodostimme kullekin komponentille manuaalisesti summamuuttujan käyttämällä vahvimmin latautuneita osioita (0.4 tai enemmän). Tämä ratkaisu mahdollisti ulottuvuuksien yhteisvaihtelun tarkastelun regressioanalyysin avulla ja on vinoon faktorointiin verrattuna yksinkertaisempi tulkita. Summamuuttujien reliabiliteettia arvioitiin Crohnbachin alfan avulla. Keskityimme regressioanalyysissa kahteen selkeään ja tilastollisesti vahvimpaan CAM-hoitoja kuvaavaan summamuuttajaan (ominaisarvo \& alfat). Lineaarisen regressioanalyysin selittävinä muuttujina käytimme tavanomaisten sosiodemografisten taustamuuttujien lisäksi muita hoitojen käyttötaipumusta kuvaavia summamuuttujia. Lisäksi 
Taulukko 3. Pääkomponenttianalyysin ominaisarvot ja lataukset viidelle komponentille (2018).

\begin{tabular}{|c|c|c|c|c|c|}
\hline & Terapia & Itsehoito & Elintavat & $\begin{array}{l}\text { Valtavirta- } \\
\text { hoidot }\end{array}$ & $\begin{array}{l}\text { Psykoterapia ja } \\
\text { hypnoosi }\end{array}$ \\
\hline $\begin{array}{l}\text { Perinteinen kiinalainen lääketiede } \\
(T C M)\end{array}$ & 0,65 & 0,00 & $-0,00$ & 0,09 & $-0,01$ \\
\hline Vyöhyketerapia & 0,61 & 0,10 & 0,09 & $-0,06$ & 0,17 \\
\hline Kansanparannus & $\mathbf{0 , 6 0}$ & 0,16 & $-0,00$ & 0,03 & $-0,05$ \\
\hline Homeopatia & $\mathbf{0 , 5 7}$ & 0,20 & 0,04 & $-0,12$ & 0,15 \\
\hline Akupunktio & 0,55 & $-0,02$ & 0,10 & 0,28 & 0,11 \\
\hline Kiropraktiikka & 0,54 & 0,03 & 0,08 & 0,15 & 0,07 \\
\hline Aromaterapia & $\mathbf{0 , 5 1}$ & 0,25 & 0,04 & $-0,15$ & 0,09 \\
\hline Luontaistuote & 0,16 & 0,77 & 0,20 & $-0,02$ & 0,07 \\
\hline Ravintolisävalmiste & 0,05 & 0,74 & 0,28 & 0,00 & 0,17 \\
\hline Rohdosvalmiste & 0,33 & 0,67 & $-0,02$ & 0,05 & $-0,03$ \\
\hline $\begin{array}{l}\text { Apteekista ilman reseptiä ostettava } \\
\text { itsehoitolääke }\end{array}$ & $-0,01$ & $\mathbf{0 , 5 1}$ & $-0,09$ & $\mathbf{0 , 4 4}$ & $-0,04$ \\
\hline Liikunta & 0,06 & 0,04 & $\mathbf{0 , 8 2}$ & $-0,02$ & $-0,01$ \\
\hline Ruokavalio & 0,06 & 0,21 & 0,79 & 0,08 & 0,03 \\
\hline Rukous & 0,23 & 0,29 & 0,30 & 0,08 & 0,10 \\
\hline Reseptilääke & $-0,06$ & 0,12 & $-0,01$ & 0,75 & 0,07 \\
\hline $\begin{array}{l}\text { Leikkaus/kirurginen toimenpide } \\
\text { julkisessa tai yksityisessä } \\
\text { terveydenhuollossa }\end{array}$ & 0,17 & $-0,05$ & 0,11 & 0,64 & $-0,02$ \\
\hline Psykoterapia & 0,05 & 0,14 & 0,12 & 0,14 & 0,76 \\
\hline Hypnoosi & 0,25 & $-0,01$ & $-0,07$ & $-0,08$ & $\mathbf{0 , 7 0}$ \\
\hline Ominaisarvot & 3,76 & 1,70 & 1,28 & 1,15 & 1,02 \\
\hline $\begin{array}{l}\text { Crohnbachin alfa } \\
\text { summamuuttujalle }\end{array}$ & 0,69 & 0,69 & 0,58 & 0,30 & 0,28 \\
\hline
\end{tabular}

Kursivoidut hoidot luokiteltu CAM-hoidoiksi.

otimme analyysiin mukaan CAM-hoitoihin uskomista kuvaavan muuttujan. Jälkiositukseen perustuvaa painokerrointa käytettiin vuosivertailussa ja regressioanalyysissä SPSS:n Complex Samples -moduulin kautta.

\section{TULOKSET}

\section{CAM-HOITOJEN KÄYTÖN YLEISYYS VUOSINA 2008-2018}

Vertasimme vuosien 2008 ja 2018 tuloksia erilaisten hoitojen käytössä (kuvio 1). Lähes kaikkien hoitojen käyttö oli vähentynyt. Tilastollisesti merkitsevä vähennys näkyi reseptilääkkeiden, apteekista ostettavien itsehoitolääkkeiden, rohdosvalmisteiden, aromaterapian, vyöhyketerapian, liikunnan, luontaistuotteiden, ravintolisävalmisteiden, ruokavalion ja rukouksen käyttöasteessa. Vuoden 2018 aineistossa käytetyimpiä hoitoja olivat leikkaus tai kirurginen toimenpide $(83.9 \%)$ sekä resepti- ja itsehoitolääkkeet $(96.7 \%$ ja
$84 \%)$, liikunta $(92.6 \%)$ ja ruokavalio $(83.1 \%)$. CAM-hoidoista yleisimpiä olivat luontaistuotteet $(53.8 \%)$ ja ravintolisät $(53.4 \%)$. Lisäksi käytetyimpiä olivat rukous $(34.3 \%)$, rohdosvalmisteet $(29.2 \%)$ sekä akupunktio $(28.1 \%)$ ja kiropraktiikka $(27.7 \%)$. Vähiten käytettyjä hoitomuotoja olivat hypnoosi $(4.4 \%)$, kiinalainen lääketiede $(5.5 \%)$ ja aromaterapia $(7.4 \%)$.

CAM-hoitojen kokonaiskäyttöä tarkastelimme summamuuttujan avulla. Muuttujaan laskettiin mukaan CAM-hoidoiksi hoidot, joita ei ole tarjolla julkisten terveyspalveluiden yhteydessä. Vastaajista $12.3 \%$ kertoi vuonna 2008 ja $17.4 \%$ vuonna 2018, ettei ollut itse tai perheenjäsen ei ollut käyttänyt mitään kyseisistä hoidoista. Muutos oli tilastollisesti merkitsevä.

USKO HOITOJEN PARANTAVUUTEEN JA HOIDOISTA SAATU APU VUOSINA 2008-2018

Usko hoitojen parantavuuteen oli pienempi vuoden 2018 aineistossa kuin vuonna 2008. Ti- 
Kuvio 1. Eri hoitomuotojen käyttö vuosina 2008-2018 (\%)

Alaviite: Erojen tilastollinen merkitsevyys on merkitty tähdillä: ***: $p \leq 0.00,{ }^{* *}: p \leq 0.01,{ }^{*}: p \leq 0.05$

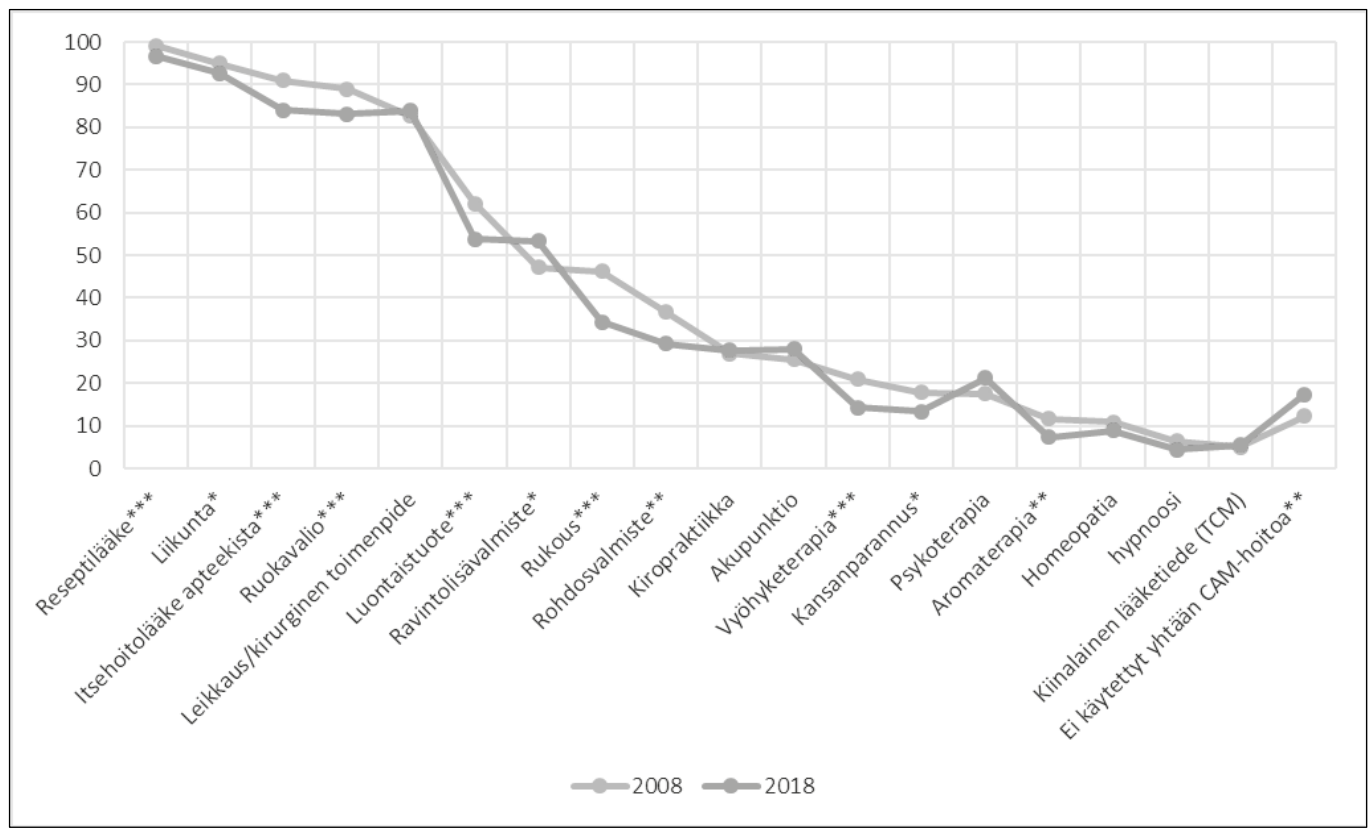

lastollisesti merkitsevästi laskua oli uskossa reseptilääkkeisiin, apteekin itsehoitolääkkeisiin, akupunktioon, homeopatiaan, vyöhyketerapiaan, aromaterapiaan, kansanparannukseen, luontaistuotteisiin ja rukouksen parantavuuteen. Kysymyksessä siitä kuinka paljon saadusta hoidosta on ollut apua ei ollut havaittavissa muutosta eri tutkimusvuosina. Kaikkien hoitojen kohdalla yli $50 \%$ vastaajista koki saaneensa apua. Eniten apua koettiin saadun perinteisistä lääketieteen hoitomuodoista, psykoterapiasta, liikunnasta ja ruokavaliosta. Myös kiropraktiikkaa ja perinteistä kiinalaista lääketiedettä käyttäneistä noin $90 \%$ raportoi saaneensa apua hoidoista. Vähiten apua raportoitiin saadun aromaterapiasta ja hypnoosista, mutta näistäkin apua koki saaneensa yli 54\% hoitoa käyttäneistä. (Taulukko 1.)

\section{ERILAISTEN CAM-HOITOJEN KäYTTÖ JA KÄYTTÖÖN LIITTYYÄT TEKIJÄT}

Tutkimme CAM-hoitojen käyttöä ja siihen liittyviä taustatekijöitä faktorianalyysin keinoin. Keskitymme kahteen tulkinnallisesti selkeimpään ja tilastollisesti vahvimpaan summamuuttujaan, joita käytämme regressioanalyysin vastemuuttujina. Näistä ensimmäinen muodostuu eri CAM-terapiamuodoista, joissa korostuu hoidon kohteena oleminen. Tälle pääkomponentille ("terapia”) la- tautuvat perinteinen kiinalainen lääketiede, vyöhyketerapia, kansanparannus, homeopatia, akupunktio, kiropraktiikka ja aromaterapia. Toinen komponentti ("itsehoitovalmisteet") muodostuu suun kautta otettavien valmisteiden käytön ympärille ja sille latautuvat luontaistuotteet, ravintolisävalmisteet, rohdosvalmisteet ja apteekista ilman reseptiä itse ostettavat lääkkeet. Ensimmäisen ryhmän hoidot ovat terapeuttisia hoitoja, joihin useimmiten liittyy hoidon asiantuntija, joka antaa hoitoa asiakkaalle. Toisessa faktorissa puolestaan hoitojen käyttäminen on itsenäisempää eikä välttämättä perustu asiantuntijan läsnäoloon. Kolmas faktori muodostuu liikunnan ja ruokavalion käyttäjistä, neljäs länsimaisen lääketieteen hoitomuodoista (leikkaus/ kirurginen toimenpide julkisessa terveydenhoidossa, reseptilääke ja apteekin itsehoitolääke). Viidenteen faktoriin latautuvat psykoterapia ja hypnoosi.

Esittelemme komponenttianalyysin perusteella tehtyjen summamuuttujien regressioanalyysin tulokset taulukossa 4. Naisilla, iäkkäämmillä ja vastaajilla, jotka asuivat alle 10000 asukkaan kaupungissa oli voimakkaampi taipumus käyttää terapia-komponentin hoitoja. Eri muotojen yhteiskäytön osalta huomasimme, että muista käyttötapasummamuuttujista ainoastaan länsimaisen lääketieteen käyttö ei ollut tilastollisesti 
Taulukko 4. Regressioanalyysi kahdelle CAM-hoitojen summamuuttujalle (2018).

\begin{tabular}{|c|c|c|c|c|c|c|c|c|c|}
\hline \multirow{3}{*}{ Sukupuoli } & \multirow[b]{3}{*}{ Nainen } & \multicolumn{4}{|l|}{ Terapia } & \multicolumn{4}{|l|}{ Itsehoito } \\
\hline & & \multirow{2}{*}{\begin{tabular}{|l} 
Estimaatti \\
$\mathbf{0 , 3 6}$
\end{tabular}} & \multicolumn{3}{|c|}{ Luottamusväli } & \multirow{2}{*}{\begin{tabular}{|l} 
Estimaatti \\
0,05
\end{tabular}} & \multicolumn{2}{|c|}{$\begin{array}{c}\text { Luottamusväl } \\
95 \%\end{array}$} & \multirow{2}{*}{$\begin{array}{l}\mathrm{p} \\
0,57\end{array}$} \\
\hline & & & 0,19 & 0,54 & 0,00 & & $-0,12$ & 0,22 & \\
\hline & Mies & . & . & . & . & . & . & . & . \\
\hline & Ikä & 0,01 & $\mathbf{0 , 0 0}$ & $\mathbf{0 , 0 2}$ & $\mathbf{0 , 0 0}$ & $-0,01$ & $-0,02$ & $\mathbf{0 , 0 0}$ & $\mathbf{0 , 0 6}$ \\
\hline \multirow[t]{3}{*}{ Koulutus } & Peruskoulu & . & . & . & . & . & . & . & . \\
\hline & $\begin{array}{l}\text { Toisen asteen } \\
\text { koulutus }\end{array}$ & 0,19 & $-0,05$ & 0,42 & 0,12 & 0,11 & $-0,11$ & 0,34 & 0,32 \\
\hline & Korkeakoulu & 0,05 & $-0,21$ & 0,31 & 0,71 & 0,26 & $\mathbf{0 , 0 2}$ & $\mathbf{0 , 5 0}$ & $\mathbf{0 , 0 3}$ \\
\hline \multirow[t]{5}{*}{ Tulot } & Alle 20000 &. &. &. &. &. &. &. &. \\
\hline & $20-40000$ & $-0,09$ & $-0,36$ & 0,18 & 0,53 & $-0,08$ & $-0,32$ & 0,17 & 0,54 \\
\hline & $40-60000$ & $-0,08$ & $-0,40$ & 0,23 & 0,60 & $-0,18$ & $-0,45$ & 0,08 & 0,17 \\
\hline & Yli 60000 & 0,20 & $-0,10$ & 0,50 & 0,19 & $-0,22$ & $-0,51$ & 0,08 & 0,15 \\
\hline & Puuttuvat & 0,00 & $-0,29$ & 0,29 & 1,00 & $-0,19$ & $-0,46$ & 0,09 & 0,19 \\
\hline \multirow[t]{4}{*}{ Työllisyys } & Työssä &. & . &. &. &. & . &. &. \\
\hline & $\begin{array}{l}\text { Työtön tai } \\
\text { hoitovapaalla }\end{array}$ & $-0,15$ & $-0,54$ & 0,24 & 0,46 & $-0,17$ & $-0,56$ & 0,23 & 0,41 \\
\hline & Opiskelija & $-0,28$ & $-0,59$ & 0,04 & 0,09 & $-0,05$ & $-0,36$ & 0,27 & 0,76 \\
\hline & Eläkeläinen & $-0,08$ & $-0,37$ & 0,21 & 0,57 & $-0,28$ & $-0,56$ & $\mathbf{0 , 0 1}$ & 0,06 \\
\hline \multirow{5}{*}{$\begin{array}{l}\text { Asuinalueen } \\
\text { koko } \\
\text { (asukasta) }\end{array}$} & Alle 10000 & 0,30 & 0,01 & 0,58 & 0,04 & $-0,27$ & $-0,54$ & $-0,00$ & 0,05 \\
\hline & $10-30000$ & 0,03 & $-0,20$ & 0,26 & 0,79 & 0,04 & $-0,17$ & 0,24 & 0,74 \\
\hline & $30-50000$ & 0,03 & $-0,32$ & 0,39 & 0,85 & 0,02 & $-0,29$ & 0,34 & 0,89 \\
\hline & $50-100000$ & $-0,07$ & $-0,29$ & 0,16 & 0,57 & $-0,09$ & $-0,33$ & 0,16 & 0,50 \\
\hline & Yli 100000 & . & . & . & . &. & . & . & . \\
\hline \multirow{4}{*}{$\begin{array}{l}\text { Hoito- } \\
\text { komponentit }\end{array}$} & Itsehoito/terapia & 0,25 & $\mathbf{0 , 1 7}$ & $\mathbf{0 , 3 3}$ & $\mathbf{0 , 0 0}$ & 0,20 & 0,14 & 0,26 & $\mathbf{0 , 0 0}$ \\
\hline & Valtavirta & 0,05 & $-0,07$ & 0,17 & 0,43 & $\mathbf{0 , 7 7}$ & 0,65 & 0,90 & $\mathbf{0 , 0 0}$ \\
\hline & $\begin{array}{l}\text { Psykoterapia \& } \\
\text { hypnoosi }\end{array}$ & 0,64 & 0,41 & $\mathbf{0 , 8 8}$ & $\mathbf{0 , 0 0}$ & 0,14 & $-0,03$ & 0,31 & 0,12 \\
\hline & Elintavat & 0,17 & 0,06 & $\mathbf{0 , 2 8}$ & $\mathbf{0 , 0 0}$ & 0,47 & 0,33 & 0,60 & 0,00 \\
\hline \multirow[t]{3}{*}{ CAM-usko } & Korkea & 0,54 & 0,19 & 0,88 & 0,00 & 0,64 & $\mathbf{0 , 3 7}$ & 0,91 & $\overline{0,00}$ \\
\hline & Puuttuvat & 0,12 & $-0,06$ & 0,30 & 0,18 & 0,15 & $-0,03$ & 0,33 & 0,10 \\
\hline & Heikompi usko & . & . & . & . & . & . & . & . \\
\hline
\end{tabular}

Alaviite 1. Tilastollisesti merkitsevät $(\mathrm{p} \leq 0.05)$ vuosierot on tummennettu

merkitsevästi yhteydessä terapiamuuttujaan. Usko CAM-hoitojen parantavuuteen oli positiivisesti yhteydessä terapiamuuttujaan.

Itsehoitovalmisteiden summamuuttujan regressioanalyysi osoittaa, että etenkin korkeasti koulutetut käyttivät itsehoitovalmisteita. Sukupuoli ei ollut tilastollisesti merkitsevä tekijä ja iän ja eläkkeellä olemisen negatiivinen yhteys itsehoitovalmisteiden käyttöön jäi hieman alle tilastollisen merkitsevyyden rajan. Pienellä paikkakunnalla asuminen vähentää itsehoitovalmisteiden käyttöä. Muista hoitomuodoista muut paitsi psykoterapia ja hypnoosi olivat merkitsevästi ja positiivisesti yhteydessä itsehoitovalmisteiden käyttöön. Erona terapiasummamuuttu- jaan itsehoito oli myös positiivisesti yhteydessä julkisen terveydenhoidon palveluiden käyttöön. Usko CAM-hoitoihin oli positiivisessa yhteydessä itsehoitovalmisteiden käyttöön.

Testasimme regressioanalyysien robustiuden painojen, asuinpaikan koon ja CAM-hoitoihin uskon suhteen. Ilman painoja tulokset olivat muuten yhteneväisiä, mutta asuinpaikan koon ja tulojen suhteen löytyi eroavuuksia kummassakin mallissa: ilman painoja korkeat tulot tulivat merkitseväksi ja asuinpaikka menetti tilastollisen merkitsevyyden. Asuinpaikan koon tai CAM-hoitoihin uskon jättäminen malleista pois ei muuttanut tuloksia. 


\section{POHDINTA}

Tulostemme mukaan CAM-hoitojen käyttö on vähentynyt viimeisen kymmenen vuoden tarkastelujaksolla. Tässä kyselyssä käyttöaste nousi yli 80 prosentin, koska siinä kysyttiin käyttöä laajasti, oman käytön lisäksi käyttöä läheisillä (ks. myös aineiston rajoitukset alla). Käytetyimmät hoitomuodot olivat suun kautta otettavat tuotteet (luontaistuotteet, ravintolisät ja rohdosvalmisteet). Muita yleisesti käytettyjä hoitomuotoja olivat rukous, akupunktio ja kiropraktiikka. Vaikka yleinen usko hoitojen parantavuuteen oli laskenut, niin hoitoja käyttäneet kokivat edelleen saaneensa hoidoista apua.

Tutkimme CAM-hoitojen käytön taustatekijöitä ja yhteyksiä eri hoitomuotojen välillä pääkomponentti- ja regressioanalyysin keinoin. Terapioita, joihin sisältyy asiantuntijan hoidettavana oleminen, käyttävät eniten naiset ja vanhemmat ikäluokat. CAM-hoitojen ja valtavirtalääketieteen käyttö eivät olleet tilastollisesti merkitsevästi yhteydessä toisiinsa eli CAM-hoidot eivät vähentäneet valtavirtalääketieteen käyttöä. Käyttö oli positiivisesti yhteydessä muihin löytämiimme komponentteihin eli vastaajat hakivat apua laajasti eri hoitomuodoista. Itsehoitotuotteita käyttivät erityisesti korkeakoulutetut, mutta tämän komponentin suhteen sukupuoli ei ollut merkitsevä tekijä. Itsehoitotuotteiden käyttö oli täydentävää ja yhteydessä valtavirtalääkinnän käyttöön sekä muihin hoitomuotoihin paitsi psykoterapiaan ja hypnoosiin. Kumpikin CAM-käyttömuoto oli vahvasti ja itsenäisesti yhteydessä uskoon hoitojen parantavuudesta.

Julkisessa keskustelussa ja tutkimuksissa usein väitetään, että CAM-hoitojen käyttö on pitkällä aikavälillä lisääntynyt merkittävästi $(1,27)$. Aineistojemme perusteella CAM-hoitojen käyttö suomalaisessa väestössä on kuitenkin kymmenen vuoden tarkasteluajanjaksolla vähentynyt eikä lisääntynyt. Yksi syy CAM-hoitojen käytön vähenemiseen voi olla julkinen keskustelu, jossa esimerkiksi lääkärikunta ottaa vahvan tuomitsevan kannan näihin hoitoihin korostaen niiden käyttöön liittyviä riskejä ja haittavaikutuksia $(8,26,36)$. Toisaalta käytön väheneminen voi johtua hoitojen nopeasti muuttuvista trendeistä. Esimerkiksi aromaterapia ja vyöhyketerapia saattoivat olla aiempana ajankohtana nykyistä suositumpia uudehkoja hoitomuotoja. Valviran nimekesuojatun, manipulatiivisiin CAM-hoitoi- hin usein luokitellun kiropraktiikan käytössä ei ollut tilastollisesti merkitsevää laskua, mikä voi tarkoittaa sen vakiintumista tiettyjen käyttäjäryhmien hoidoksi. Toisaalta näiden mieltäminen terveydenhuollon ulkopuolisiksi voi olla erilaista kuin muissa CAM-hoidoissa, koska koulutetut kiropraktikot, naprapaatit ja osteopaatit ovat kuuluneet jo vuodesta 1994 terveydenhuollon nimekesuojattuihin ammatteihin (16).

Tutkimuksemme vahvistaa aiempien tutkimusten tuloksia siitä, että CAM-hoidot ovat käyttäjien näkökulmasta arvioiden monille merkittävä keino hoitaa terveyttä ja huolehtia hyvinvoinnista. Osa hoitomuodoista voisi olla käsitettävissä terveyttä edistäviksi hyvinvointihoidoksi, ei sairautta hoitaviksi. Osaa hoidoista saatetaan käyttää lääkärien määräämien hoitojen vaihtoehtona. Joka tapauksessa kyseessä on laaja terveydenhoidollinen ilmiö, joka vaatii seurantaa ja joka vaikuttaa terveydenhuollon ammattilaisten ja asiakkaiden kohtaamisissa.

\section{AINEISTON RAJOITUKSET}

Tutkimuksemme ei pyri ratkaisemaan kaikkia alussa kuvattuja CAM-käyttötutkimuksen vertailtavuuden ongelmia. Aineiston rajoituksista voidaan mainita muissakin CAM-tutkimuksissa vallitseva ongelma kysymyksenasettelusta: tässä tutkimuksessa oli kysytty hyvin laveasti, onko vastaaja itse tai joku hänen perheenjäsenensä käyttänyt hoitoja. Näin ollen vastaukset eivät kerro tarkasti henkilökohtaisesta käytöstä. Lisäksi kysymykselle ei ollut asetettu aikarajausta, joka olisi tarkentanut käyttöastetta esimerkiksi viimeisen 12 kuukauden aikana. Kysytyssä hoitomuotojen listassa ei ole esimerkiksi hierontaa, joka usein nostaa käyttöastetta lisää. Esimerkiksi Kajava-terapia ja hermoratahieronta ovat luokiteltavissa CAM-hoidoiksi, kun taas klassiset hierojat ovat Valviran rekisteröimä ammattikunta (vrt. taulukko 1).

Tutkimukseen tulivat mukaan vain ne CAMhoidot, jotka oli mainittu ensimmäisessä, vuoden 2008 kyselyssä. Siksi monet itsehoitona sovellettavat CAM-hoidot, kuten jooga, tai chi tai qi gong, joiden käyttö Yhdysvalloissa oli lisääntynyt eniten tarkastelujaksolla 2002-2012 (21), eivät olleet mukana tässä tutkimuksessa. Myöskään mindfulness ei ollut mukana tutkimuksessa. Kansanparannus-termi saattoi vuonna 2018 vaikuttaa vanhahtavalta. Rukouksen mukanaolo 
tutkimuksessa on ongelmallista, koska sen voi ymmärtää enemmän uskonnolliseksi kuin terveydenhoidon toiminnaksi.

Asuinalueen kokoa koskevia tuloksia voi pitää korkeintaan suuntaa antavina. Kyseessä on hierarkkisesti yksilötasoa ylemmän tason tieto, jolloin jo aineiston luonnollinen ryvästyminen heikentää estimoinnin tehoa. Näin ollen saadut merkitsevyystasot ovat liian pieniä. Toisaalta tulos on kuitenkin itse kertoimien tasolla varsin vahva, joten pidimme muuttujan sisällyttämistä perusteltuna keskustelunavauksen mielessä.

Koska aineisto ei ole tavanomainen satunnaisotos perusjoukosta eikä saatavilla ollut tarkkoja yksikkökohtaisia otantatietoja otannan erityispiirteiden huomioimiseksi, tehdyt tilastolliset testit olettavat painotukseen perustuvan yksinkertaisen satunnaisotannan. Oletus on sikäli perusteltu, että taustalla on kaksi eri suuntiin vaikuttavaa tekijää: yhtäältä aineiston ryvästyminen heikentää otoksen tehoa, mutta kiintiöinnin voi katsoa muistuttavan eräiltä osin ositusta, joka taas parantaa tehoa. Näin ollen nämä tekijät kumoavat osittain toistensa vaikutusta, jolloin oletus yksinkertaisesta satunnaisotannasta on lopulta sopivin käytettävissä oleva lähestymistapa. Yhtä kaikki haluamme korostaa, että tulokset ovat vain suuntaa antavia, minkä vuoksi tulkinnoissa on syytä olla maltillinen.

\section{RAHOITTAJAT:}

Tutkimus on saanut rahoitusta Emil Aaltosen säätiöltä (Terveys, tieto ja asiantuntijuus -projekti), Koneen Säätiöltä (Crossing Borders for Health and Well-being -projekti) ja Suomen Akatemialta (rahoitusnumero 312310: Ikääntymisen ja hoivan tutkimuksen huippuyksikkö; Strategisen tutkimuksen neuvoston rahoitusnumerot 327145 ja 327148: DigiIN-hanke).

\section{KIRJOITTAJIEN KONTRIBUUTIOT:}

Vuolanto vastasi käsikirjoituksen laatimisesta. Laura Kemppainen ja Teemu Kemppainen vastasivat tilastollisen aineiston käsittelystä ja analyysistä. Nurmi osallistui tutkimuksen suunnitteluun ja analyysiin. Kaikki kirjoittajat osallistuivat käsikirjoituksen kirjoittamiseen.

\section{Vuolanto, P., Kemppainen, L., Kemppainen, T., Nurmi, J. The use of complementary and alternative treatments (CAM) in Finland. Sosiaalilääketieteellinen aikakauslehti - Journal of Social Medicine 2020: 57: 44-56.}

This article explores the use of complementary and alternative medicine (CAM) in Finland in 2008 and 2018. CAM therapies are a diverse set of treatments that are not included in mainstream medicine at a certain historical and societal context. Use of CAM modalities alongside officially accepted treatments is a significant phenomenon seldom researched in Finland. The aim of the research was to analyze how much Finns used CAM-therapies and the changes in the usage from year 2008 to 2018. We studied the treatments that the respondents used and perceived good effects of the treatments. We used data collected by Taloustutkimus and analyzed it with Khi square test, explorative component analysis and linear regression analysis.

Our results show that the use of CAM had decreased during past ten years. The most used CAM modalities were those that taken by mouth (natural products, dietary supplements and medicinal drugs). Other frequently used CAM was prayer, acupuncture and chiropractic. Although belief in the treatments had decreased, those us- ing the treatments has still received help from the treatments. The use of CAM did no decrease use of mainstream medicine. The respondents used treatments broadly.

Keywords: complementary and alternative medicine, CAM, use of CAM, belief medication, Finland.

$\begin{array}{cc}\text { Saapunut } & 09.04 .2019 \\ \text { Hyväksytty } & 06.08 .2019\end{array}$

\section{LÄHTEET}

(1) Sosiaali- ja terveysministeriö. Vaihtoehtohoitojen sääntelyn tarve. Vaihtoehtohoitoja koskevan lainsäädännön tarpeita selvittäneen työryhmän raportti 2009. Luettu 15.1.2020. http://urn.fil URN:ISBN:978-952-00-2810-7

(2) Fulder S. The basic concepts of alternative medicine and their impact on our views of health. J Altern Complement Med 1998; 2: 147-158.

(3) National Center for Complementary and Integrative Health. Complementary, Alternative, 
or Integrative Health: What's In a Name? Luettu 15.1.2020.

https://nccih.nih.gov/health/integrative-health

(4) Kemppainen L, Kemppainen T, Reippainen

J, Salmenniemi S, Vuolanto P. Use of complementary and alternative medicine in Europe: Health-related and sociodemographic determinants. Scand J Public Health 2017. doi: $10.1177 / 1403494817733869$

(5) Use of Complementary and Alternative Medicine by the American Public Staff, Board on Health Promotion and Disease Prevention Staff, Institute of Medicine Staff, et al. Complementary and Alternative Medicine in the United States. Washington, D.C: National Academies Press; 2005;2004. Luettu 15.1.2020. https://www.ncbi. nlm.nih.gov/books/NBK83804/\#ch1.s2

(6) U.S.National Library of Medicine. Complementary Therapies MeSH descriptor data. Luettu 15.1.2020. https://meshb.nlm.nih. gov/record/ui?ui=D000529

(7) Danell JA, Danell R. Publication activity in complementary and alternative medicine. Scientometrics 2009;80:539-551.

(8) Salminen V. Syövän vaihtoehtohoidot. Duodecim 2017;133:2102-9.

(9) Mäkelä M, Haapoja H. Puoskaroinnista lääketieteeseen ja takaisin. Duodecim 2016;132;2169-75.

(10) Gale N. The sociology of traditional, complementary and alternative medicine. Sociol Comp 2014;8:805-822.

(11) Hemilä H. Uskomuslääkintä on harhaanjohtava termi. Duodecim 2016;132:1389-90

(12) Hokkanen M, Kananoja K. Kiistellyt tiet terveyteen. Parantamisen monimuotoisuus globaalihistoriassa. Helsinki: SKS; 2017.

(13) Seppänen J, Kamaja M, Myllykangas M, Tuomainen T-P. CAM ei ole neutraali termi. Suomen Lääkäril 2016;71:2404-2405.

(14) Vuolanto P, Sorsa M, Aarva P, Helin K. Katsaus suomalaiseen CAM-tutkimukseen. Sosiaalilääketiet Aikakausl 2018;55:243-259.

(15) Vuolanto, P. The incompatibility between social worlds in complementary and alternative medicine: The case of therapeutic touch. Kirjassa: Brosnan C, Vuolanto P, Brodin Danell JA. (toim.) Complementary and alternative medicine: Knowledge production and social transformation. Cham: Palgrave Macmillan; 2018, 59-84.

(16) Valvira. Terveydenhuollon ammattioikeudet 2017. Luettu 15.1.2020. https://www.valvira.fi/ terveydenhuolto/ammattioikeudet

(17) Danell JA, Danell R, Vuolanto P. Scandinavian research on complementary and alternative medicine: A bibliometric study. Scandinavian Journal of Public Health 2019. doi: 10.1177/1403494819834099

(18) Hemilä H. Vaihtoehtohoito voi joskus perustua näyttöön. Suomen Lääkäril 2016;71(18):1298-9.
(19) Louhiala P, Hemilä H. Can CAM treatments be evidence-based? Perspective. Focus on Alternative and Complementary Therapies. 2014;19:84-89.

(20) Quandt SA, Ip EH, Saldana S, Arcury TA. Comparing two questionnaires for eliciting CAM use in a multi-ethnic US population for older adults. European Journal of Integrative Medicine 2012;4:e205-e211.

(21) Clarke T, Black LI, Stussman BJ, et al. Trends in the use of complementary health approaches among adults; United States, 2002-2012. Natl Health Stat Report 2015; 79:1-16.

(22) Koithan M. Introducing Complementary and Alternative Therapies. J Nurse Pract 2009; 1: 18-20.

(23) Quandt SA, Verhoef MJ, Arcury TA, Lewith GT, Steinsbekk A, Kristoffersen AE, et al. Development of an International Questionnaire to Measure Use of Complementary and Alternative Medicine (I-CAM-Q). Journal of Alternative \& Complementary Medicine 2009 04;15(4):331-339.

(24) Bryden GM, Browne M. Development and evaluation of the R-I-CAM-Q as a brief summative measure of CAM utilisation. Complementary Therapies in Medicine 2016;27: 82-86.

(25) Siahpush M. A critical review of the sociology of alternative medicine: research on users, practitioners and the orthodoxy. Health 1999;4:159-178.

(26) Lääkäriliitto. 14.12.2017. Suositus lääkärin suhtautumisesta uskomushoitoihin. Luettu 15.1.2020. https://www.laakariliitto.fi/ edunvalvonta-tyoelama/suositukset/suosituslaakarin-suhtautumisesta-uskomushoitoihin/

(27) Vaskilampi T, Meriläinen P, Sinkkonen S. The use of alternative treatments in the Finnish adult population. Complem Med Res 1992;6:9-20.

(28) Vartiainen E, Koskela K, Tikkanen J ym. Vaihtoehtoisten hoitomuotojen käyttö Suomessa 1992. Kirjassa: Koskela K, Vaskilampi T, Vartiainen E, Meriläinen P, Viinamäki H, Mäntyranta T. (toim.) Vaihtoehtolääkintä Suomessa 1982-1992. Helsinki: Sosiaali- ja terveysministeriön selvityksiä 3; 1993, 13-36.

(29) Peltzer K, Pengpid S. Prevalence and determinants of traditional, complementary and alternative medicine provider use among adults from 32 countries. Chinese Journal of Integrative Medicine 2018; 24: 584-590.

(30) Eardley S, Bishop F, Prescott ym. A systematic literature review of complementary and alternative medicine prevalence in EU. Forsch Komplementmed 2012;19:18-28.

(31) Vaskilampi T, Vartiainen E, Meriläinen P, ym. Vaihtoehtolääkinnän tuntemuksen ja käytön muutoksia - tuloksia kymmenvuotisseurannasta. Kirjassa: Koskela K, Vaskilampi T, Vartiainen E, Meriläinen P, Viinamäki H, Mäntyranta T. (toim.) Vaihtoehtolääkintä Suomessa 19821992. Helsinki: Sosiaali- ja terveysministeriön selvityksiä 3; 1993, 63-78. 
(32) Canizares M, Hogg-Johnson S, Gignac MAM, Glazier RH, Badley EM. Changes in the use practitioner-based complementary and alternative medicine over time in Canada: Cohort and period effects. PLoS ONE 2017;12(5).

(33) Tainya C. Clarke; Patricia M. Barnes, Lindsey I. Black, Barbara J. Stussman, and Richard L. Nahin. Use of Yoga, Meditation, and Chiropractors Among U.S. Adults Aged 18 and Over. NCHS Data Brief, No. 325, November 2018.

(34) Pokladnikova J, Selke-Krulichova I. The Use of Complementary and Alternative Medicine by the General Population in the Czech Republic: A Follow-Up Study. Comp Med Res 2018;25(3):159-166.

(35) Puska J. 2018. Taloustutkimus. Henkilökohtainen tiedonanto.

(36) Pälve H. Vaihtoehtoiset hoidot eivät kuulu lääketieteeseen. Potilaan lääkärilehti 20.2.2018. Luettu 15.1.2020. http://www. potilaanlaakarilehti.fi/laakarit-ottavat-kantaa/ laakariliiton-palve-vaihtoehtoiset-hoidot-eivatkuulu-laaketieteeseen/
Pia Vuolanto

Dosentti, tutkija

Tampereen yliopisto

Yhteiskuntatieteiden tiedekunta

Tiedon, tieteen, teknologian ja innovaatioiden tutkimuskeskus TaSTI

\section{LAURA KEMPPAINEN}

VTT, yliopistotutkija

Helsingin yliopisto

Valtiotieteiden tiedekunta

Ikääntymisen ja boivan tutkimuksen huippuyksikkö

DigiIN-hanke

Teemu Kemprainen

VTT, yliopistonlehtori

Helsingin yliopisto

Geotieteiden ja maantieteen laitos

JoHANna NuRmi

VTT, tutkijatohtori

Tampereen yliopisto

Yhteiskuntatieteiden tiedekunta

Terveystieteet 